\title{
Avoiding Stent-in-Stent Retrieval Strategy for Partially Covered Stents in Anastomotic Leakages: An Innovative Approach
}

\author{
Gonçalo Nunes $^{\mathrm{a}}$ Marta Patita ${ }^{\mathrm{a}}$ Pedro Pinto-Marques ${ }^{\mathrm{a}, \mathrm{b}}$ \\ ${ }^{a}$ Gastroenterology Department, Hospital Garcia de Orta, Almada, Portugal; ${ }^{b}$ Gastroenterology Department, \\ Hospital da Luz, Lisbon, Portugal
}

Keywords

Anastomotic leakage $\cdot$ Dehiscence $\cdot$ Self-expandable metal stent

\section{Evitando a estratégia de remoção "stent-in-stent" para próteses parcialmente cobertas em deiscências de anastomoses: uma abordagem inovadora}

\section{Palavras Chave}

Anastomose · Deiscência · Prótese metálica autoexpansível

Anastomotic leakage is still one of the most feared surgical complications with an incidence of 3-25\% [1]. The endoscopic placement of self-expanded metallic esophageal stents has become the preferred primary treatment with an $85 \%$ clinical success [2]. Fully covered metal stents (FCMS) are prone to migration due to its reduced anchoring capacity and partially covered metal stents (PCMS) cause tissue ingrowth as early as 1 week after placement, impairing its removal with risk of bleeding and perforation [2]. The stent-in-stent technique requires

\section{KARGER}

E-Mail karger@karger.com www.karger.com/pjg (c) 2018 Sociedade Portuguesa de Gastrenterologia Published by S. Karger AG, Basel

Karcer

$\checkmark$ pen access

This article is licensed under the Creative Commons AttributionNonCommercial-NoDerivatives 4.0 International License (CC BYNC-ND) (http://www.karger.com/Services/OpenAccessLicense). Usage and distribution for commercial purposes as well as any distribution of modified material requires written permission. placement of an FCMS inside the PCMS during 10-14 days to induce pressure necrosis of the overgrowing and ingrowing mucosa, allowing further safe removal [3].

An 82-year-old woman previously submitted to total gastrectomy due to gastric adenocarcinoma was newly diagnosed with a colorectal adenocarcinoma. A left hemicolectomy was performed but an incidental laceration of a proximal jejunal loop complicated the procedure and a new esophagojejunal anastomosis had to be accomplished. Few days after surgery, signs of sepsis developed and an esophagojejunal anastomosis leakage was confirmed. Gastroenterology consultation was requested for stent placement. In the upper gastrointestinal endoscopy, a 5-mm orifice with a milky draining fluid was detected $32 \mathrm{~cm}$ from the incisors. A PCMS $23 \times 120 \mathrm{~mm}$ was placed and fixed with endoscopic clips after extensive cauterization of the tissue surrounding the fistula orifice (Fig. 1). Two weeks later, a follow-up outpatient endoscopy showed a $2-\mathrm{cm}$ distal migration, albeit the orifice was still covered. Overgrowing tissue was present but the stent could be easily repositioned. The stent remained in place for two additional weeks and later was easily removed without complications. The orifice was completely sealed at this time and the patient remained asymptomatic (Fig. 2).

Dr. Gonçalo Nunes

Gastroenterology Department, Hospital Garcia de Orta

Av. Torrado da Silva

PT-2805-267 Almada (Portugal)

E-Mail goncalo.n@ @otmail.com 

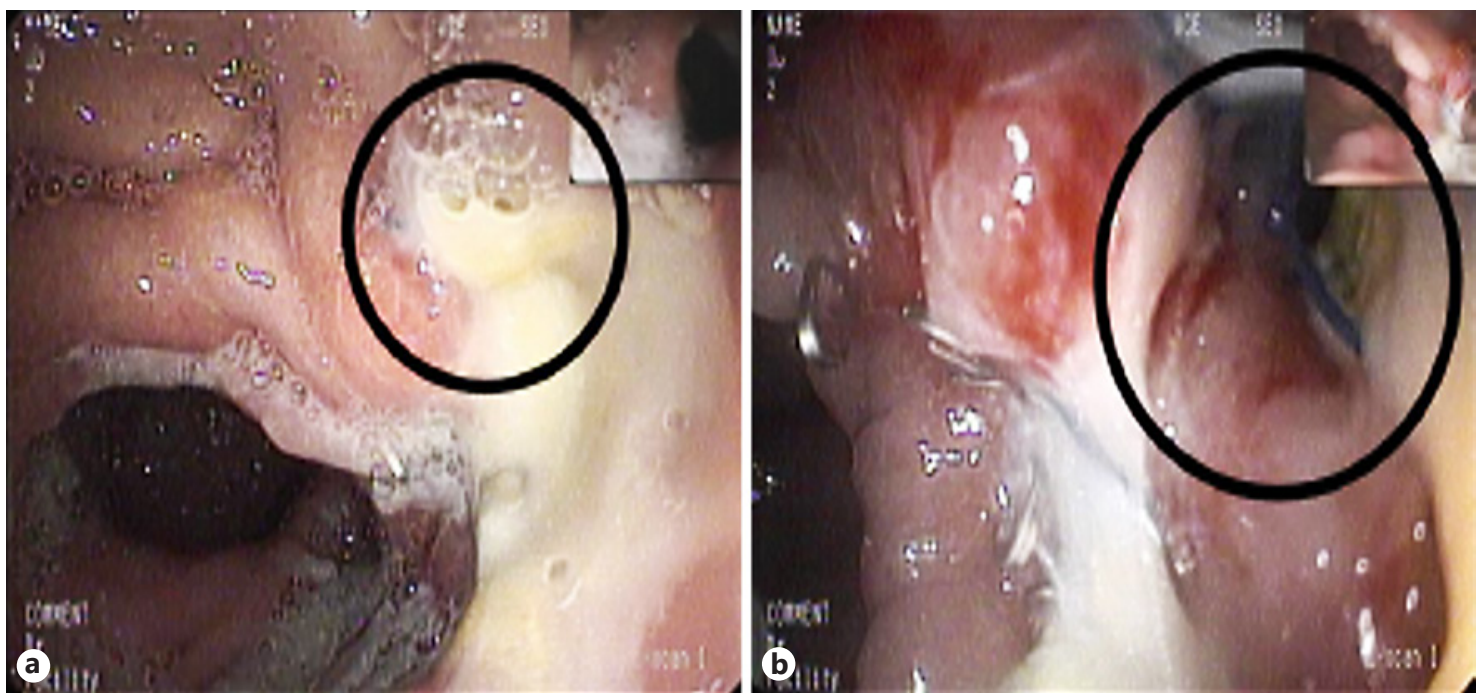

Fig. 1. Esophagojejunal anastomotic leakage. a First endoscopy after surgery showing a 5-mm orifice at the level of esophagojejunal anastomosis draining purulent fluid. b Appearance after careful inspection and extensive washing and aspiration.
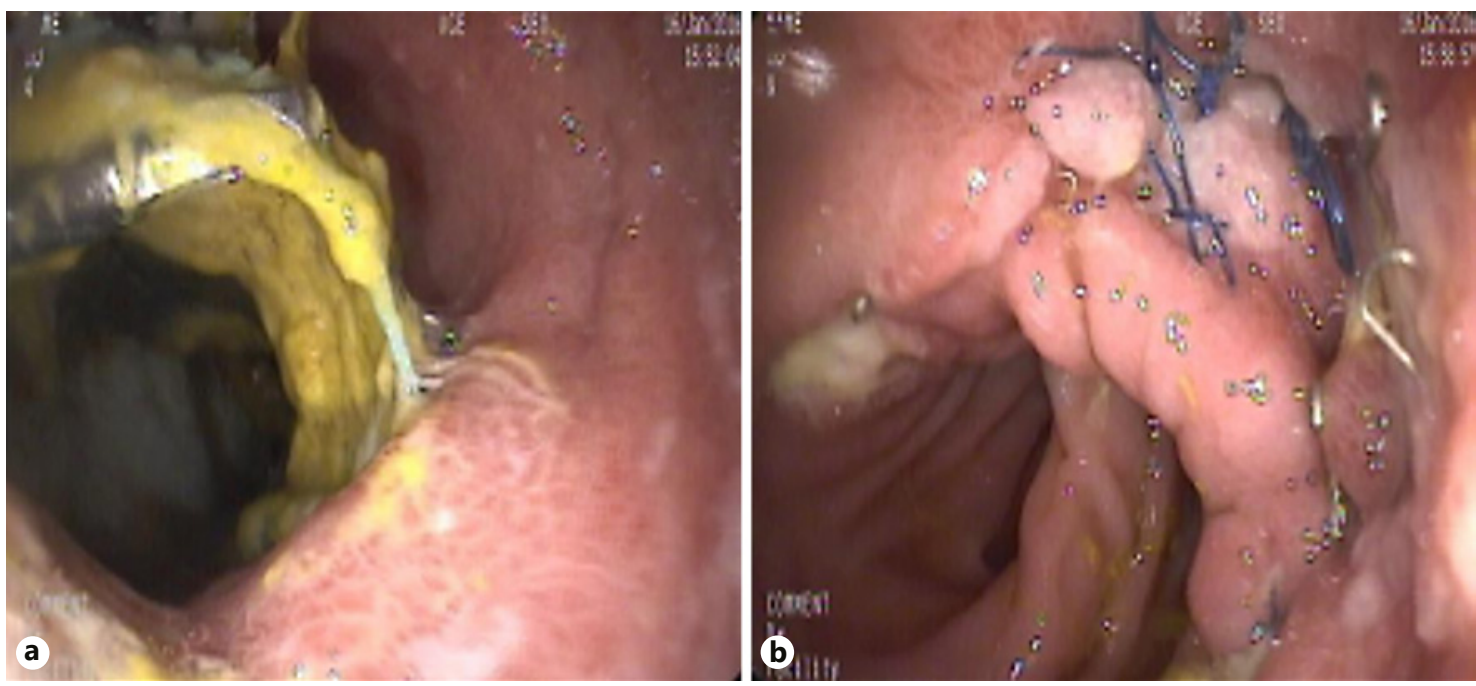

Fig. 2. Esophagojejunal anastomosis after 4 weeks of stenting. a PCMS in situ and permeable. b Complete sealing of the dehiscence with exuberant granulation tissue after stent removal.

Anastomotic leakages are associated with high mortality. A conservative approach with stent placement avoids surgical re-intervention. Although the stenting period should be individualized, 6-8 weeks is the period described for an effective sealing in most studies [3]. In the present report, an innovative approach to manage anastomotic leakages, not previously reported in the literature, is exemplified as an alternative to the stent-in-stent technique when PCMS are applied. This strategy was de- veloped after the incidental stent migration observed in this patient and taking into account the obtained good results. The authors propose PCMS placement in patients with upper gastrointestinal anastomotic leakage leaving the stent for 2 weeks. Endoscopy should be repeated at this time and the stent moved a few centimeters proximally to avoid extensive ingrowth/overgrowth through the mesh. These steps should be repeated every 2 weeks until 6-8 weeks, the mean time described for successful 
sealing of most dehiscences. This simple and safe approach may be more convenient to patients and medical staff, avoiding the risks and cost of placing a new stent and being less time-consuming and easily performed by all endoscopists even by those who are not completely trained with fluoroscopic equipment. Further studies are desirable to confirm the cost-effectiveness of this method.

\section{Disclosure Statement}

There are no conflicts of interest regarding this paper and its publication.
1 Persson S, Rouvelas I, Kumagai K, et al: Treatment of esophageal anastomotic leakage with self-expanding metal stents: analysis of risk factors for treatment failure. Endosc Int Open 2016;4:E420-E426.

2 van Boeckel PG, Sijbring A, Vleggaar FP, et al: Systematic review: temporary stent placement for benign rupture or anastomotic leak of the oesophagus. Aliment Pharmacol Ther 2011;33:1292-1301.

3 Spaander MC, Baron TH, Siersema PD, et al: Esophageal stenting for benign and malignant disease: European Society of Gastrointestinal Endoscopy (ESGE) Clinical Guideline. Endoscopy 2016;48:939-948. 